\section{Giant tortoises hatch on Galapagos island}

For the first time in 150 years and after more than 50 years of conservation efforts, the number of saddleback giant tortoises (Chelonoidis ephippium) seems set to recover unaided on Pinzón Island in the Galapagos archipelago. Rats, early whalers and pirates almost wiped out these ancient creatures.

We found ten tiny, newly hatched saddleback tortoises on the island early last month. There could be many more, because their size and camouflage makes them hard to spot. Our discovery indicates that the giant tortoise is once again able to reproduce on its own in the wild.

The Galapagos National Park and its collaborators set up a programme to save the tortoise in the 1960s, when only about 100 animals remained. This involved collecting eggs and raising hatchlings in captivity for 4-5 years to reach 'rat-proof' size, as well as drastic rateradication measures (see Nature 497, 306-308; 2013). These strategies have now enabled the species to stabilize itself. Washington Tapia Aguilera Galapagos Conservancy, Santa Cruz, Galapagos, Ecuador. Jeffreys Málaga Galapagos National Park, San Cristóbal, Galapagos, Ecuador.

James P. Gibbs State University of New York College of Environmental Science and Forestry, Syracuse, USA. jpgibbs@esf.edu

\section{Natural history: save Italy's museums}

You call attention to the crisis in Italy's natural history museums — in funding, personnel and administration, as well as in their visibility, research and purpose (Nature 515, 311-312; 2014). There is a way to prevent the long-term management of these scientific collections from deteriorating into an elitist hobby.

The Italian education and heritage ministries should together facilitate a functional and administrative connection between the country's smaller natural history museums. Such a 'meta-museum' could coordinate long-term goals and scientific activities, enabling facilities and budgetary and technical resources to be shared - as in Germany's Senckenberg Research Institute and Natural History Museum in Frankfurt and Leibniz Association in Berlin. The largest of the museums could stay as independent scientific institutions, similar to London's Natural History Museum and the National Museum of Natural History in Paris.

To strengthen their scientific influence, these museums must participate in survey work and field research that contributes to the discovery, conservation and promulgation of national and global biodiversity.

Franco Andreone ${ }^{\star}$ Museo Regionale di Scienze Naturali, Turin, Italy.

franco.andreone@regione. piemonte.it

${ }^{\star}$ On behalf of 28 correspondents (see go.nature.com/c9bcvt for full list).

\section{Natural history: first museologist's legacy}

As the Italian philosopher and naturalist Ulisse Aldrovandi lay ill in November 1603, he dictated his last will and testament - a remarkable and inspiring manifesto of scientific museology. He bequeathed his monumental collections and writings to be held in public trust so that they would be maintained for future generations of scholars. Sadly, his collections are among those now languishing in disarray in Italy (see Nature 515, 311-312; 2014).

Aldrovandi conceived the idea of a natural history museum, the first of which was created as a public institution in Bologna in 1547. He introduced the concept of a sample type for any fossil species, an idea that was expanded during his lifetime by Francesco Calzolari in Verona, Michele Mercati in Rome and Ferrante Imperato in Naples underscoring Italy's crucial role in the birth and development of natural history museums.

We have carelessly ignored the will of a great father of museology. It is time to make amends by spurring a renaissance of these museums in Italy. Marco Romano Sapienza University of Rome, Italy.

Richard L. Cifelli Sam Noble Museum, Norman, Oklahoma, USA. Gian Battista Vai University of Bologna, Italy.

rlc@ou.edu

\section{Use mentoring to fix science inequality}

We suggest that mentorship is particularly important for scientists from the developing world (see Nature 515, 453-454; 2014). It can address the problem of science inequality while helping to resolve global issues.

Academics in developing countries are rarely able to take advantage of cuttingedge knowledge from leading universities, more than $90 \%$ of which are in high-income nations (see go.nature.com/wffbfi). Expenditure on research and development is typically less than $1 \%$ of gross domestic product one-third of the amount spent by most developed nations (see go.nature.com/gio8pu).

Scientists from wealthy countries could be encouraged to mentor young scientists from developing nations by including mentorship requirements in grant awards, for example.

Also, allocating resettlement funding can help to counter the 'brain drain' of researchers leaving low-income countries. It encourages them to return to share experience and knowledge and build local capacity.

Malgorzata Blicharska Swedish Biodiversity Centre, Uppsala, Sweden.

Grzegorz Mikusiński Swedish
University of Agricultural Sciences, Skinnskatteberg, Sweden. malgorzata.blicharska@slu.se

\section{IPBES responds on conflicts of interest}

Contrary to the impression given by Axel Hochkirch and colleagues (Nature 516, 170; 2014), the Intergovernmental Platform on Biodiversity and Ecosystem Services (IPBES) is expected to approve a policy on conflicts of interest for authors at this week's third plenary in Bonn, Germany.

The IPBES has rules and procedures for nominating and selecting experts from a wide variety of sectors to ensure credibility and transparency (see go.nature.com/zh1osy). Accordingly, these experts are nominated by governments and stakeholders and selected by our Multidisciplinary Expert Panel.

Our interim conflict-ofinterest policy is in operation for the pollinators assessment (completed declaration forms available from the secretariat on request). The scientists from agrochemical companies mentioned by Hochkirch et al. were selected in their capacity as independent scientists to provide objective input for the pollination report. Moreover, independent peer review of all IPBES texts guards against any bias.

Reports by other global and regional assessment panels routinely include authors from commercial sectors - for example, the Intergovernmental Panel on Climate Change and the International Assessment of Agricultural Knowledge, Science and Technology for Development. The latter was even accused of being unbalanced when industrial scientists withdrew from the assessment process (see Nature 451, 223-224; 2008).

Anne Larigauderie ${ }^{\star} I P B E S$, Bonn, Germany.

anne.larigauderie@ipbes.net ${ }^{*}$ On behalf of 4 correspondents (see go.nature.com/swyese for full list). 